\title{
c-kit Receptor and Ligand Expression in Postnatal Development of the Mouse Cerebellum Suggests a Function for c-kit in Inhibitory Interneurons
}

\author{
Katia Manova, ${ }^{1,2, a}$ Rosemary F. Bachvarova, ${ }^{2}$ Eric J. Huang, ${ }^{1}$ Sandra Sanchez, ${ }^{1}$ Stephen M. Pronovost, ${ }^{1}$ Eric \\ Velazquez, ${ }^{1,3}$ Barbara McGuire, ${ }^{2,3}$ and Peter Besmer ${ }^{1}$ \\ Molecular Biology Department, Sloan Kettering Institute and Cornell University Graduate School of Medical Sciences, \\ New York, New York 10021, 2Department of Cell Biology and Anatomy, Cornell University Medical College, New York, \\ New York 10021, and 'Laboratory of Neurobiology, Rockefeller University, New York, New York 10021
}

The c-kit receptor and its cognate ligand, $\mathrm{KL}$, are encoded at the white spotting locus (W) and the steel locus (SI) of the mouse, respectively. SI and $W$ mutations affect the same cellular targets in melanogenesis, gametogenesis and hematopoiesis during embryonic development and in adult life. c-kit is expressed in cellular targets of $\boldsymbol{W}$ and $\boldsymbol{S} /$ mutations, whereas $K L$ is expressed in the microenvironment of these targets. C-kit and $\mathrm{KL}$, however, are also expressed in tissues and cell types that are not targets of $W$ and $S I$ mutations, including the brain. The cerebellum contains a small number of neural cell types whose developmental origins, pathways of migration, and synaptic contacts are known. We have investigated the patterns of expression of the c-kit and KL RNA and protein products in postnatal cerebellar development of the mouse. In the adult cerebellum, c-kit RNA and protein expression was evident in basket, stellate, and Golgi neurons. Most strikingly, the c-kit protein is expressed in the basket cell axons that form "basket" and "pinceau" structures entwining the Purkinje cell soma and the initial segment of the Purkinje cell axon. KL RNA expression was found in Purkinje cells, and the $K L$ protein was detected in Purkinje cell bodies and dendrites. Soluble KL protein was also present in c-kit-expressing basket, stellate, and Golgi cells, presumably as a result of internalization of ligandreceptor complexes. During postnatal development, c-kit and KL RNA and protein expression in Golgi and Purkinje neurons, respectively, was evident by day 0 and persisted subsequently. c-kit expression in basket and stellate cells was detected from their time of birth, starting at day 4 . These results suggest a role for the c-kit receptor system in postnatal development of the cerebellum.

\footnotetext{
Received Feb. 24, 1992; revised Apr. 28, 1992; accepted May 29, 1992.

We thank Dr. Carlos Cordon-Cardo and Carlos Moreno for their invaluable help with histochemistry, and Drs. Jerome Posner, Karl Nocka, and Regina Buck for stimulating discussions and comments on the manuscript. This work was supported by grants from the National Institutes of Health to P.B. (R37 CA 32926), R.F.B. (HD 06910), and B.M. (NEIEY 06792). E.J.H. was the recipient of a Horsefall fellowship.

Correspondence should be addressed to Peter Besmer, Sloan Kettering Institute, 1275 York Avenue, New York, NY 10021.

Permanent address: Institute of Cell Biology and Morphology, Bulgarian Academy of Sciences, Sofia, Bulgaria.

Copyright (C) 1992 Society for Neuroscience $0270-6474 / 92 / 124663-14 \$ 05.00 / 0$
}

Increasing evidence implicates several tyrosine kinase receptor systems in neurogenic processes. NGF, brain-derived neurotrophic factor, and neurotrophin-3 were recently shown to be ligands of the c-trk, c-trkB, and c-trkC tyrosine kinase receptors, respectively (Kaplan et al., 1991; Lamballe et al., 1991; Squinto et al., 1991). These factors regulate cell survival, differentiation, and neurotransmitter synthesis of distinct sets of neurons (for a revicw, sec Barde, 1989). In vitro, basic fibroblast growth factor enhances the survival and differentiation of granule neurons (Hatten et al., 1988), hippocampal neurons (Walicke et al., 1986), and PC12 cells (Rydel and Green, 1987), and platelet-derived growth factor (PDGF) stimulates the proliferation of $\mathrm{O}-2 \mathrm{~A}$ oligodendrocyte-astrocyte progenitor cells in rat optic nerve cultures, thus preventing their differentiation (Noble et al., 1988; Rafl el al., 1988). In agreement with an in vivo function for tyrosine kinase receptors in neurogenesis, the expression of the receptors and/or their ligands was shown to be restricted to particular cell types using in situ hybridization and/or histochemistry (e.g., Klein et al., 1990; Lai and Lemke, 1991; Sasahara et al., 1991; Yeh et al., 1991).

The proto-oncogene c-kit encodes a transmembrane tyrosine kinase receptor belonging to the PDGF receptor subfamily (Besmer et al., 1986; Yarden et al., 1987; Majumder et al., 1988; Qiu et al., 1988). The ligand of the c-kit receptor, KL, also called steel factor, is synthesized from two alternatively spliced mRNAs as transmembrane protein(s) that may be proteolytically cleaved to produce a soluble form(s) of $\mathrm{KL}$ or to function as cell-associated molecules (Nocka et al., 1990; Flanagan et al., 1991; Huang et al., 1992). The c-kit receptor and its ligand, KL, are encoded, respectively, at the white spotting $(W)$ and steel $(S l)$ loci of the mouse (Chabot et al., 1988; Geissler et al., 1988; Nocka et al., 1989, 1990; Copeland et al., 1990; Zsebo et al., 1990a,b). Both $S l$ and $W$ mutations affect cellular targets in melanogenesis, gametogenesis, and hematopoiesis during development and in adult life, implying a function for the c-kit receptor in these cell systems (Russell, 1979; Silvers, 1979). In agreement with this notion, c-kit is expressed in targets of $W$ and $S /$ mutations during embryonic development and postnatal gametogenesis and in cells of the hematopoietic system (Nocka et al., 1989; Manova et al., 1990; Orr-Urtreger et al., 1990; Manova and Bachvarova, 1991). The mutant defects are consistent with a role of the c-kit receptor system in promoting cell proliferation, cell survival, and cell migration of precursor cells as well as enhancing functions of more differentiated cells. 
However, c-kit is also expressed in cell types that are apparently not affected by $W$ and $S l$ mutations. During embryonic development, c-kit expression is seen in the neural tube, portions of the forebrain, midbrain and hindbrain, the olfactory epithelium, dorsal root ganglia, the digestive tract, the lung, and other tissues (Orr-Urtreger et al., 1990; Keshet et al., 1991; Manova and Bachvarova, 1991). In the adult animal, c-kit expression is prominent in the brain, including the cerebellum, and in the lung.

The objective of the present study was to investigate the expression of c-kit and KL during postnatal development of the cerebellum to gain insight into a possible role for the c-kit receptor in these cell systems. The developmental origin, pathways of migration, and functions and connectivity of cerebellar neurons have been studied extensively (Ramon y Cajal, 1911; for reviews, see Palay and Chan-Palay, 1974; Jacobson, 1978; Ito, 1984). The Purkinje cell is the principal neuron of the cerebellum and provides the only output. The local circuit neurons of the cerebellum include the Golgi, granule, and Lugaro cells, which make up the granular layer, and the basket and stellate cells, which constitute the molecular layer. Basket cell axons form synapses with the soma of Purkinje cells, and the stellate cells form synapses with the dendritic shafts of Purkinje cells, both exerting an inhibitory action. Granule cells receive input from mossy fibers, while their axons, the parallel fibers, synapse in the molecular layer, with dendrites of Purkinje, basket, stellate, and Golgi cells. Golgi cells receive their main inputs from mossy fiber terminals and minor ones from Purkinje cell axons and climbing fiber axons, while in turn they form inhibitory synapses with granule cells.

The cells of the cerebellum develop initially from the proliferative epithelium lining the fourth ventricle (Angevine and Sidman, 1961; Miale and Sidman, 1961; Fujita et al., 1966; Fujita, 1967; Altman, 1969, 1972, 1982; Trenckner et al., 1984; Altman and Bayer, 1985; Rakic, 1985; Hallonet et al., 1990). At birth, the external germinal layer overlies the Purkinje and Golgi cells and contains closely packed proliferating cells (Miale and Sidman, 1961; Fujita et al., 1966; Fujita, 1967). Granule cells are born postnatally in the external germinal layer between about postnatal day 5 (P5) and P15 and then migrate radially inward through the molecular and the Purkinje cell layers to form the granular layer in association with the Golgi cells. Basket and stellate cells originate from the external germinal layer in two overlapping waves between about postnatal day P3-P8 and P5-P12, respectively, and form the molecular layer.

Our results show that in the developing and adult cerebellum, c-kit RNA and protein are expressed in basket, stellate, and Golgi interneurons, while KL RNA and protein are expressed in Purkinje cell neurons. The synchronous expression of the $\mathrm{c}$ kit receptor and its ligand $\mathrm{KL}$ in close cellular environments suggests a role for the c-kit receptor system in inhibitory interneurons of the cerebellum during postnatal development as well as in the adult.

\section{Materials and Methods}

Mice. Mice for these studies were C57B16/I (RNA blot and RNase protection experiments) or were derived from mating ICR females to CB6F, males.

In situ hybridization. Cerebellum or whole brains were fixed overnight in paraformaldehyde, and paraffin sections were prepared. The slides were hybridized to ${ }^{35} \mathrm{~S}$-labeled c-kit or KL RNA probes essentially as previously described (Manova et al., 1990). The c-kit probe was transcribed from a 3.6 kilobase insert including the entire coding region of the message. The KL probe was synthesized from the pcDNAl-KL plasmid, which contains the entire KL coding sequence after cleavage with BglII. The lowest level of labeling over a region of closely packed cells was taken as the background level. This was very similar to the level seen with a c-kit sense probe. Hybridization of the c-kit probe was carried out at $65^{\circ} \mathrm{C}$; hybridization of the $\mathrm{KL}$ probe was carried out using the same conditions or lower-stringency conditions as previously described (Matsui et al., 1990) with comparable results. All in situ hybridization results reported were seen in preparations from at least three animals. All experiments with the c-kit probe included control tissues such as juvenile ovaries (Manova et al., 1990).

Immunohistochemistry. Antiserum to the c-kit receptor was obtained in rabbits by injecting vaccinia modified to express the entire c-kit protein (Nocka et al., 1990). KL antiserum was obtained by immunizing rabbits with purified fibroblast-derived $\mathrm{KL}$ or a C-terminal $\mathrm{KL}$ peptide (YMLQQKEREFQEV). Both antisera and control rabbit serum were partially purified by DEAE Affi-Gel Blue (Bio-Rad) chromatography to enrich for immunoglobulins, and the anti-KL-peptide antibody was further purified by affinity chromatography. Cryostat sections were cut at $5-20 \mu \mathrm{m}$ from fresh or fixed brains or cerebellum by standard techniques, or $40 \mu \mathrm{m}$ frozen sections were prepared from brains fixed by perfusion with $2-4 \%$ paraformaldehyde in $0.1 \mathrm{M}$ sodium phosphate $(\mathrm{pH}$ 7) followed by overnight postfixation and immersion in $40 \%$ sucrose in phosphate buffer. Sections were fixed in acetone for $10 \mathrm{~min}$ and stained with the Vectastain Elite ABC kit (Vector Laboratories) using a biotinylated secondary goat anti-rabbit IgG antibody followed by an avidinbiotinylated horseradish peroxidase complex detected with diaminobenzidine. For cryostat sections, column fractions of c-kit antisera were used at dilutions of approximately 1:150 for one and at 1:1000 for a second antiserum, and of the KL antibody at 1:100 to $1: 300$. For frozen sections, the column fractions were diluted 1:900. The manufacturer's instructions for the procedure were followed except that the quenching of endogenous peroxidase was carried out in $0.1 \% \mathrm{H}_{2} \mathrm{O}_{2}$ in phosphatebuffered saline (PBS) for $15 \mathrm{~min}$, and incubation in $10 \%$ normal goat serum in PBS with $2 \%$ BSA for 30 min was included as a blocking agent for the secondary antibody, as well as an extra step to block nonspecific binding using the avidin/biotin blocking kit from Vector Laboratories. For frozen sections, incubation in primary antibody was extended to $17-65 \mathrm{hr}$ and subsequent steps to 2-12 hr. Most sections were counterstained with Harris's hematoxylin to stain nuclei blue, dehydrated, and mounted in Permount.

$R N A$ blot and RNase protection analysis. Total RNA from tissues and cell lines was prepared by homogenization in RNAzol B solution (Biotecx Lab. Inc., TX), and RNA was isolated according to the manufacturers instructions. Total cellular RNA $(15 \mu \mathrm{g})$ was fractionated in $1.2 \%$ agarose-formaldehyde gels and transferred to a nylon membrane as described previously (Nocka et al., 1989). Ethidium staining of $18 \mathrm{~S}$ and 28S RNA was used to assess equal loading of the RNA samples. An RNA probe for RNA blot analysis and RNase protection assays was prepared after linearizing the KL-1-containing pcDNAI plasmid with HindIII using SP6 polymerase and ${ }^{32} \mathrm{P}-\mathrm{CTP}$ according to the Promega Gemini kit. Prehybridization and hybridization were at $62^{\circ} \mathrm{C}$ in $50 \%$ formamide, $50 \mathrm{mM} \mathrm{NaPO}_{4}(\mathrm{pH} 6.5), 5 \times \mathrm{SSC}$ (saline-sodium citrate), $2.5 \times$ Denhardt's, $0.1 \%$ SDS, and $200 \mu \mathrm{g} / \mathrm{ml}$ salmon sperm DNA and yeast $t R N A$. Posthybridization washes were done at room temperature, for each $30 \mathrm{~min}$, consecutively in $5 \times \mathrm{SSC} / 0.05 \% \mathrm{SDS}, 2 \times \mathrm{SSC} / 1 \mu \mathrm{g}$ $\mathrm{ml} \mathrm{RNase} \mathrm{A,} 1 \times \mathrm{SSC} / 0.1 \% \mathrm{SDS}$, and $0.1 \times \mathrm{SSC} / 0.1 \% \mathrm{SDS}$. For RNase protection assays, the riboprobe was hybridized to 10 or $20 \mu \mathrm{g}$ of total RNA in the presence of $80 \%$ formamide at $45^{\circ} \mathrm{C}$ overnight. The hybridization mixture was digested with RNase $A$ and T1 (BoehringerMannheim) and treated with proteinase $\mathrm{K}$, and the protected labeled RNA fragments were analyzed on a $4 \%$ urea/polyacrylamide gel. Autoradiograms of the RNase protection assay were analyzed by densitometry, and parts of the films were reconstructed on a Phospholmage analyzer (Molecular Dynamics) for better resolution.

\section{Results}

Expression of c-kit and KL RNA and protein products in the mature cerebellum

Histogenesis of the cerebellum and generation of functional connections are complete by $\mathrm{P} 20$, and analysis of P20 or adult (2 months or older) cerebellum gave comparable results. By in situ hybridization analysis, expression of c-kit RNA was strong in 

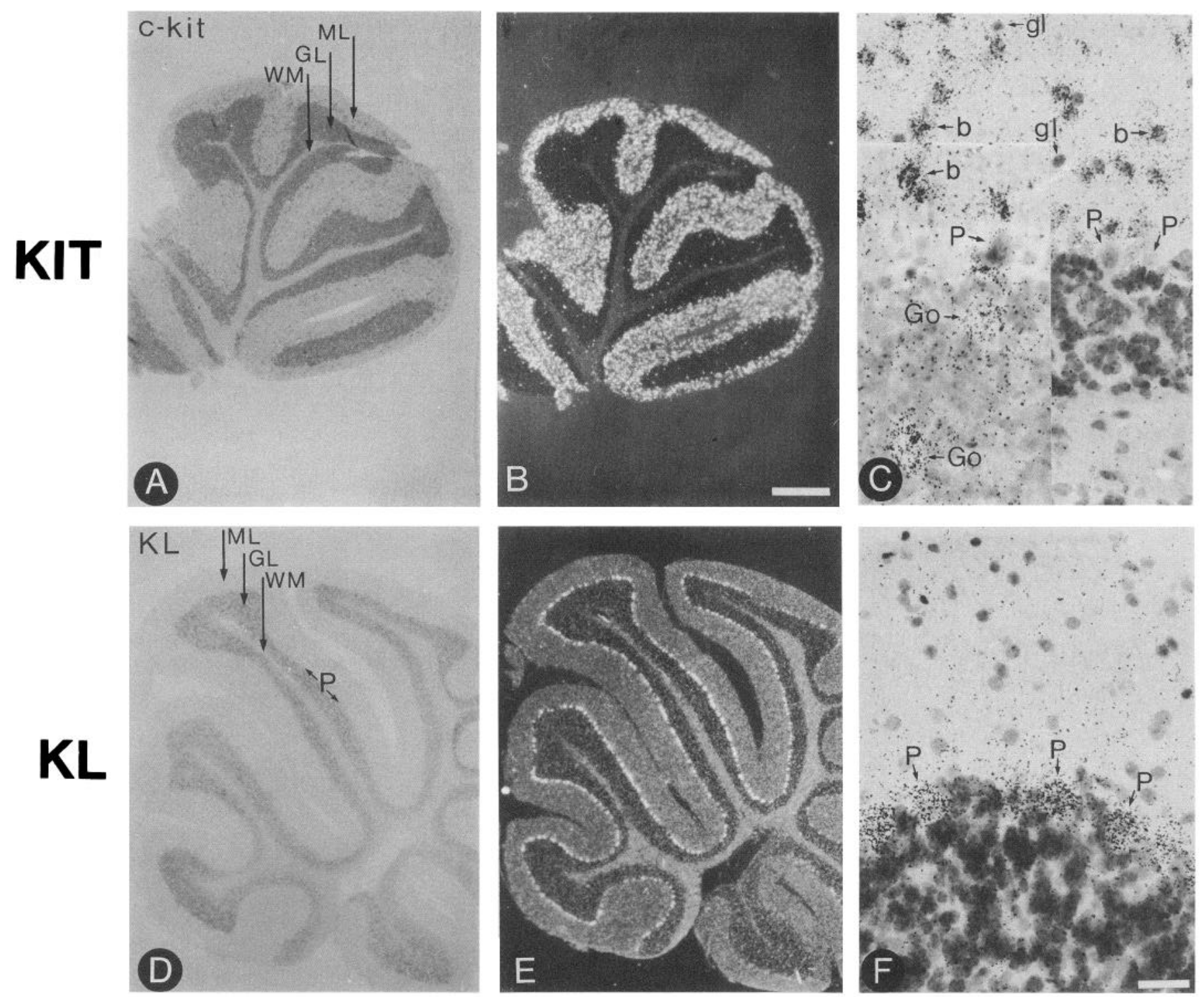

Figure 1. In situ hybridization analysis of the expression of c-kit and KL RNAs in mature cerebellum. $A$ and $B$, Bright-field $(A)$ and corresponding dark-field $(B)$ images of P20 cerebellum hybridized to the c-kit probe. $C$, High-magnification view of cells expressing c-kit RNA. Basket (b) and stellate $(s)$ cells are named according to their position, but this does not reliably distinguish them from each other. $D$ and $E$, Bright-field $(D)$ and corresponding dark-field $(E)$ images of adult cerebellum hybridization to the KL probe. $F$, High-magnification view of KL-expressing cells. For other abbreviations, see Appendix. Scale bars: $B, 500 \mu \mathrm{m}$ for $A, B, D$, and $E ; F, 25 \mu \mathrm{m}$ for $C$ and $F$.

most or all basket and stellate cells of the molecular layer and in scattered cells of the granular layer (Fig. $1 A-C$ ). These latter cells were neurons of moderate size (between that of Purkinje cells and granule cells) (Fig. $1 C$ ), were much less numerous than granule cells, and were commonly located close to Purkinje cells and also scattered throughout the granular layer. By these properties, we identified these cells as Golgi cells. Whether other neurons of the granular layer, such as Lugaro cells (Sahin and Hockfield, 1990), were labeled was not determined. Labeled cells were rare in the white matter, while some neurons of the deep cerebellar nuclei were labeled (not shown).

By immunohistochemical analysis, the c-kit protein was most prominently expressed in the "pinceau," a cluster of basket cell axon terminals that surrounds the initial segment of the axon at the base of the Purkinje cell (Fig. $2 B-D$ ) (see Palay and Chan-
Palay, 1974, for a description of the pinceau). When the plane of section was appropriate, it was seen that each Purkinje cell was associated with a single immunostained pinceau, and the pinceau was continuous with the "basket" of basket cell axons around the Purkinje cell body (Fig. $2 C, D$ ). In addition, c-kit protein was evident in the thin rim of cytoplasm of basket and stellate cell bodies and in a network of radiating stellate and basket cell processes, including axons descending to form the baskets and pinceaux (Fig. 2D). It was apparent that essentially all neurons of the molecular layer were stained. In the granular layer, Golgi cells were stained (Fig. 2D), and additional light irregular staining suggested c-kit protein expression in mossy fibers (Fig. 2B). Some neurons in the deep cerebellar nuclei were stained as well. Sections treated in parallel with preimmune rabbit serum showed only low levels of background staining 


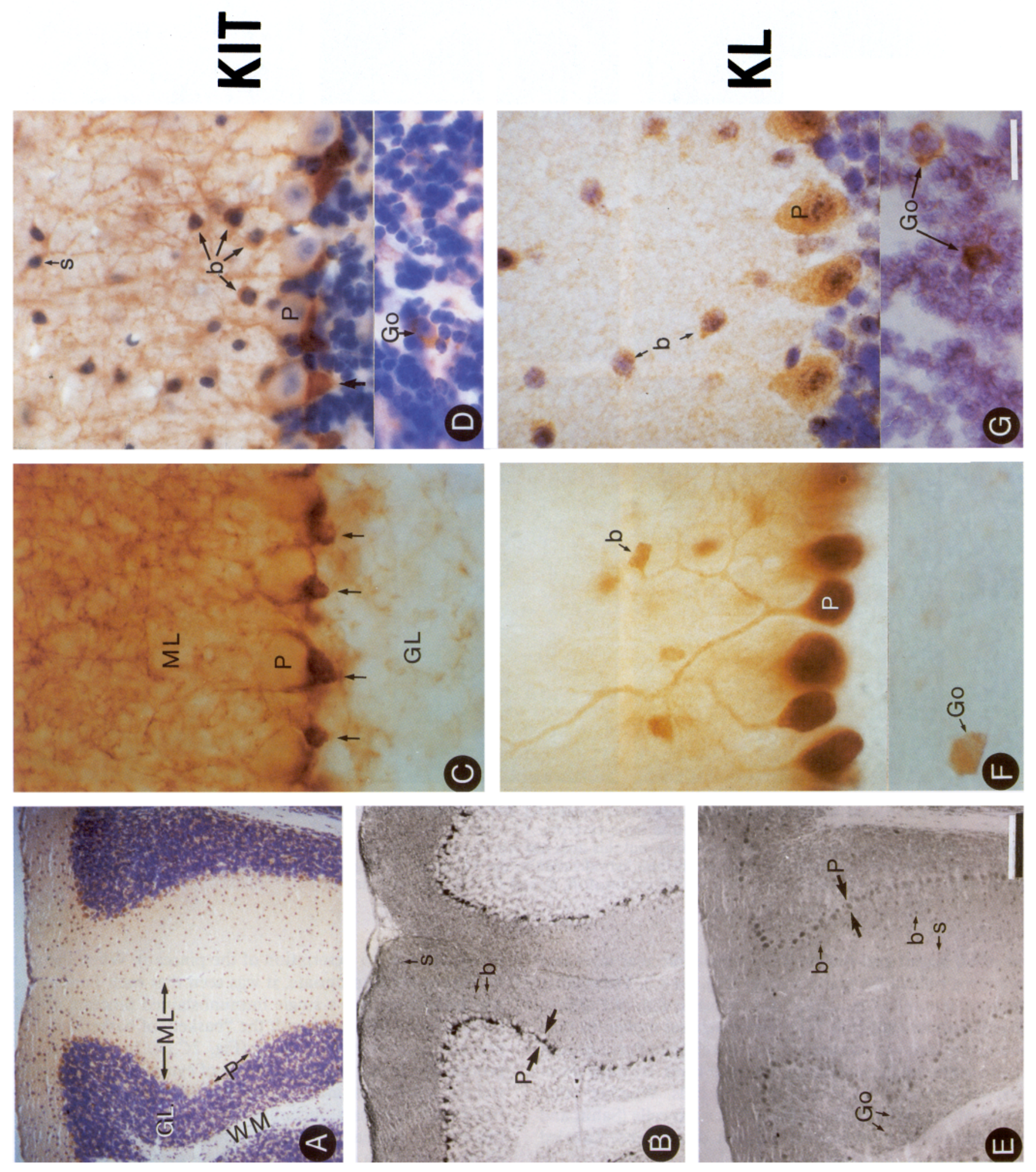



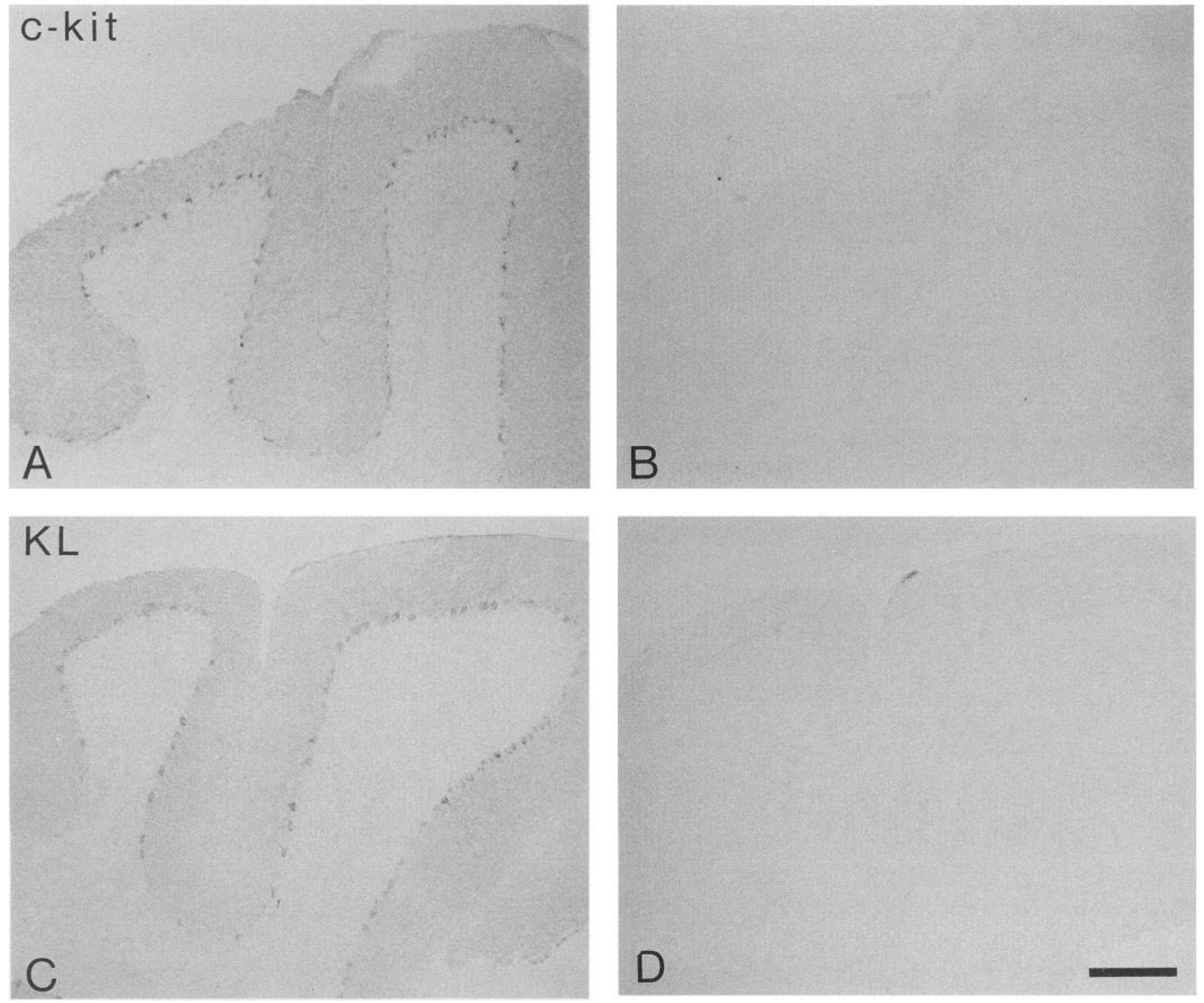

Figure 3. Specificity of c-kit and KL protein staining in 4 week cerebellum. $A$ and $B$, Adjacent sections stained in parallel with anti-c-kit immune $(A)$ and preimmune serum $(B) . C$ and $D$, Staining of adjacent sections with affinity purified anti-KL-peptide antibody specific for the KL C-terminus in the absence $(C)$ and presence $(D)$ of competing peptide $(25 \mu \mathrm{g} / \mathrm{ml})$. In $C$, note absence of staining of basket, stellate, and Golgi cells. Scale bar, $200 \mu \mathrm{m}$ for $A-D$.

(Fig. 3B). Thus, three cerebellar neuronal cell types, basket, stellate, and Golgi cells were shown to express both c-kit RNA and protein products.

An analogous analysis of the expression of KL RNA and protein products in the mature cerebellum was carried out in order to determine if the kit ligand and c-kit are expressed in neighboring and/or functionally related cell types. In P20 and adult cerebellum, in situ hybridization experiments showed that KL RNA expression was restricted to Purkinje cells (Fig. $1 D$
F). By immunohistochemical analysis, KL protein expression was most obvious in Purkinje cells (Fig. $2 E-G$ ); the staining was seen throughout the cytoplasm, and in favorable preparations, staining was also evident in at least the larger branches of the dendritic trees of the Purkinje cells (Fig. $2 F$ ). Furthermore, perinuclear staining with the $\mathrm{KL}$ antibody was seen in basket, stellate, and Golgi cells (Fig. $2 E-G$ ). Taken together, KL RNA and protein products are both expressed in cerebellar Purkinje cell neurons, and in addition, KL protein appears in c-kit-ex-

Figure 2. Expression of c-kit and $\mathrm{KL}$ protein in adult cerebellum detected by immunohistochemistry. All preparations were $10 \mu \mathrm{m}$ sections of fresh-frozen cerebellum unless indicated. $A-D$ are sections stained with anti-c-kit antibody. $C$ and $D$ are high-magnification views. $A$, Low-power view of counterstained adult cerebellum for orientation, particularly to show the granular layer. $B$, Section is not counterstained and thus reveals the overall distribution of c-kit protein. $C$, Arrows indicate stained pinceaux ( $40 \mu \mathrm{m}$ section of fixed material). $D$, Counterstained fixed section showing stained processes emanating from basket and stellate cells. Arrow below Purkinje cell $(C)$ indicates pinceau structure. A stained Golgi cell $(G o)$ taken from another section of the same material is shown in the granular layer. $E-G$, Sections stained with anti-KL antibody. $F$ and $G$ are high-magnification views. $E$, Low-power view without counterstain. $F$, High-power view of $40 \mu \mathrm{m}$ section of fixed material. $G$, Counterstained section. For other abbreviations, see Appendix. Scale bars: $E, 200 \mu \mathrm{m}$ for $A, B$, and $E ; G, 20 \mu \mathrm{m}$ for $C, D, F$, and $G$. 

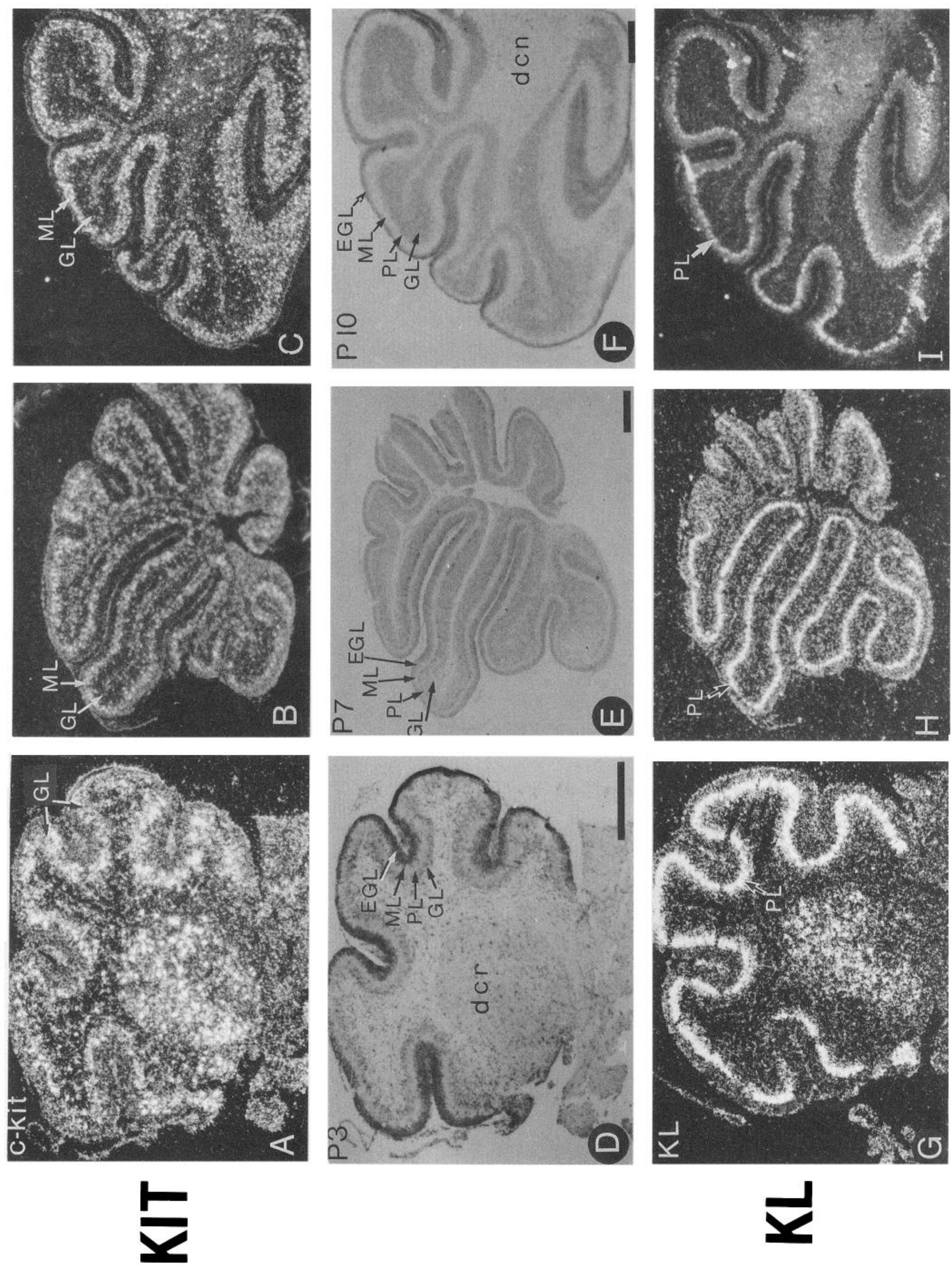

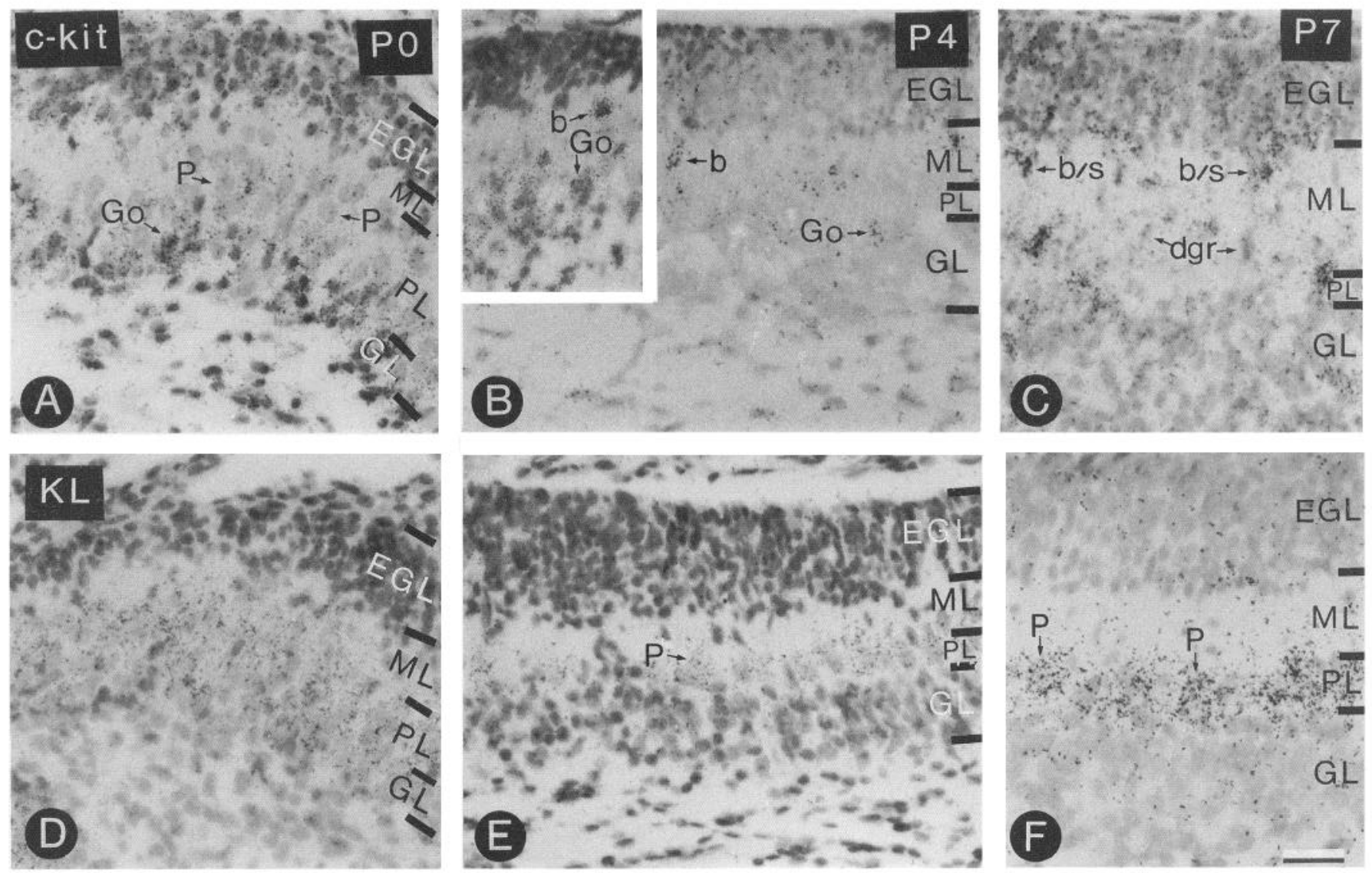

Figure 5. High-magnification images of expression of c-kit and KL RNAs in developing postnatal cerebellum. $A-C$ were hybridized to the c-kit probe; $D-F$ were hybridized to the KL probe. $A$ and $D, \mathrm{P} 0 ; B$ and $E, \mathrm{P} 4 ; C$ and $F, \mathrm{P} 7$. In $C$, note that presumed descending granule cells $(d g r)$ are not labeled. For other abbreviations, see Appendix. Scale bar, $25 \mu \mathrm{m}$ for $A-F$.

pressing cells. Sections treated in parallel with normal rabbit serum showed little background staining except a slight reaction with Purkinje cells (not shown). To differentiate between the soluble KL protein product and the cell-membrane forms, an antibody specific for the C-terminus of the cell-membrane forms of $\mathrm{KL}$ was prepared. This antibody specifically stained Purkinje cells and not basket, stellate, and Golgi cells, and the staining reaction could be competed with the peptide used for the immunization (Fig. $3 D$ ). Thus, the KL reactivity seen in basket, stellate, and Golgi cells does not contain the C-terminus of the cell-associated forms of KL and therefore, presumably, represents material taken up by c-kit receptor-mediated internalization.

\section{Expression of $c$-kit and KL RNA and protein products during postnatal cerebellar development}

$c$-kit $R N A$ and protein expression. In order to determine whether the c-kit receptor-ligand system could play a role during the generation of stellate and basket cells and during differentiation and establishment of functional connections of all cerebellar neurons, expression was examined from birth onward (P0-P20). At birth, the cerebellar cortex consists of four layers: the external germinal layer, a thin layer with sparsely scattered cells where the molecular layer will form, an irregular layer of Purkinje cells several cells thick, and an underlying irregular layer of Golgi cells partly interdigitated with the Purkinje cells (Jacobson, 1978). Beneath these are the future white matter and deep cerebellar nuclei. By P3, the molecular layer is slightly thicker and the Purkinje cell layer is thinning to form a monolayer. Hybridization of sections of $\mathrm{P} 0$ and $\mathrm{P} 3$ cerebellum to the c-kit probe gave similar results: the most prominent label appeared as a broad fuzzy layer (Fig. 4A). At high magnification, it could be seen that Purkinje cells were not labeled, and we inferred from their position that the labeled cells were Golgi cells (Fig. $5 \mathrm{~A}$ ). The external germinal layer was labeled slightly above background, while small cells in the white matter and some neurons in the deep nuclei expressed c-kit RNA at a moderate level (Fig. 4A).

At P4-P10, during the period of generation of basket, stellate,

Figure 4. In situ hybridization analysis of the expression of c-kit and $\mathrm{KL}$ in developing postnatal cerebellum. A-C are sections hybridized to the c-kit probe; $G-I$ are nearby sections of the same cerebellum hybridized to the KL probe; $D-F$ show corresponding bright-field images. $A$, The layer of labeled cells at the site of the forming granular layer $(G L)$ is identified as Golgi cells. Some neurons of the deep cerebellar nuclei are labeled. $B$, The densely packed labeled cells are newly generated basket cells of the molecular layer, and labeled Golgi cells are sparsely distributed in the granular layer. In $G-I$, the prominent layer of labeled cells located between the molecular and granular layers is composed of Purkinje cells. Some neurons of the deep cerebellar nuclei are labeled. $A, D$, and $G, \mathrm{P} 3 ; B, E$, and $H, \mathrm{P} 7 ; C, F$, and $I$, P10 cerebellum. For other abbreviations, see Appendix. Scale bars, $250 \mu \mathrm{m}$. 

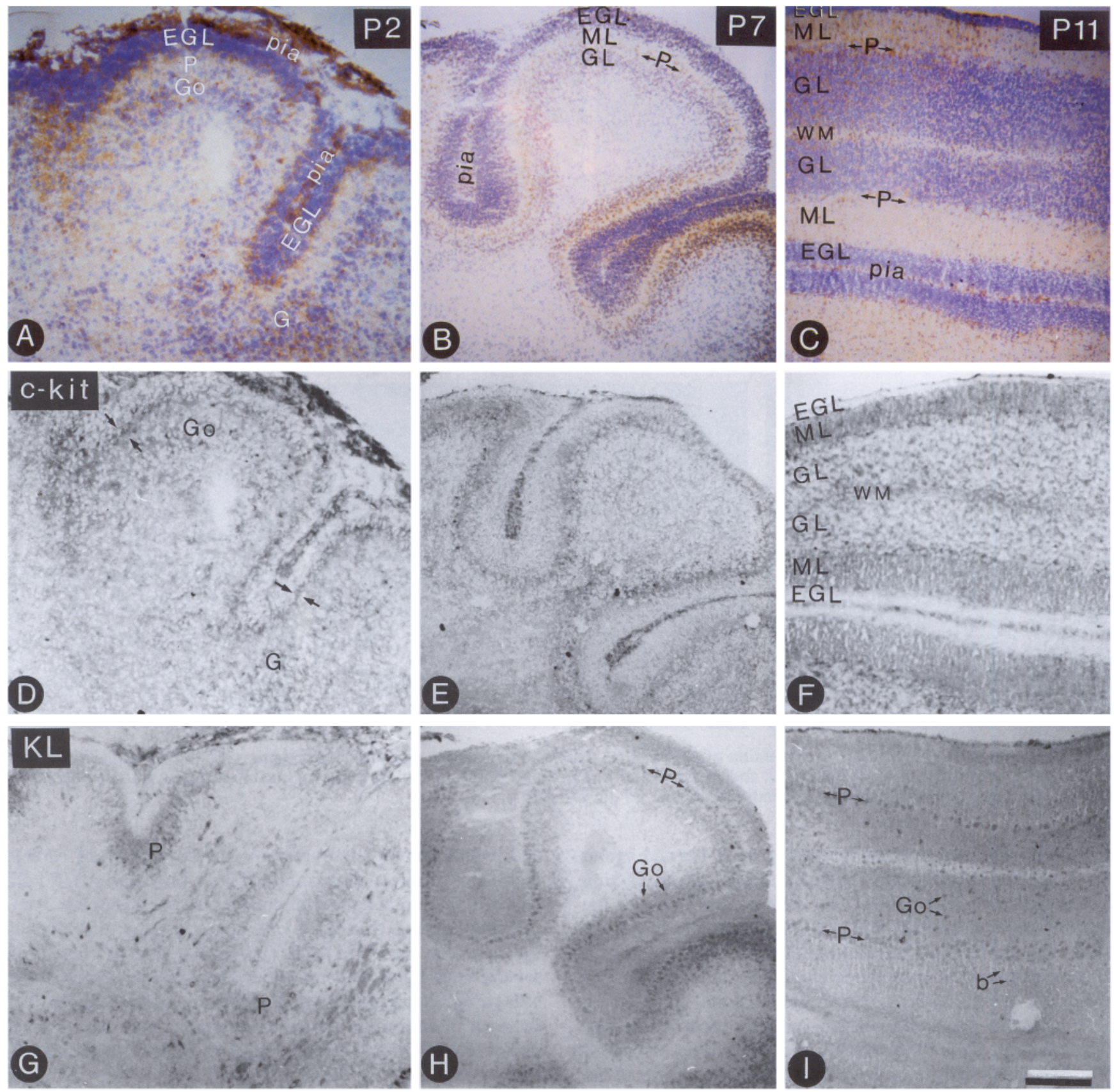

Figure 6. Expression of c-kit and $\mathrm{KL}$ proteins in developing cerebellum. All sections were taken from fresh-frozen material. $A$ and $C-F$ are sections stained with anti-c-kit antibody; $B$ and $G-I$ are sections stained with anti-KL antibody. $A, D$, and $G, \mathrm{P} 2 ; B, E$, and $H$, P7; $C, F$, and $I, \mathrm{P} 11$ cerebellum. All sections at a given age taken from the same cerebellum, except $G$. $A-C$, Counterstained sections for orientation. $D$, The inner premigratory zone of the external germinal layer is stained (arrows), as well as some cells in the granular layer (Golgi cells), and the meninges including the pia mater. $E$, The band of staining within the cortex represents both the molecular layer and Golgi cells. $F$, Staining is prominent throughout the molecular layer, and a coarser network of stain is seen in the granular layer. The pia mater is stained. In $G-I$, the Purkinje layer is stained. Golgi cells $(G o, H$ and $I)$ and basket $(b)$ and stellate cells $(I)$ are stained. For other abbreviations, see Appendix. Scale bar: $100 \mu \mathrm{m}$ for $A, D$, and $G ; 200 \mu \mathrm{m}$ for $B, C, E, F, H$, and $I$.

Figure 7. High-magnification views of expression of c-kit and KL protein in developing cerebellum. $A-C$ were stained with anti-c-kit antibody. $D-F$ were stained with anti-KL antibody. $A$ and $D, \mathrm{P} 2 ; B$ and $E, \mathrm{P} 7 ; C$ and $F, \mathrm{P} 11$ cerebellum. $A$, The inner premigratory zone (IPZ) of the external germinal layer is stained quite homogeneously. Clusters of stained presumed Golgi cells are indicated by arrows. A presumed newborn basket cell is at $b . B$ and $C$, Purkinje, basket, and Golgi cells are indicated. Arrows point to precursor or newborn basket or stellate cells. $D-F$, Examples of stained Purkinje, Golgi, and basket cells are indicated. In $E$, the Golgi cell, and in $F$, the Purkinje cell are taken from other sections of the same material. For other abbreviations, see Appendix. Scale bar, $20 \mu \mathrm{m} A-F$. 

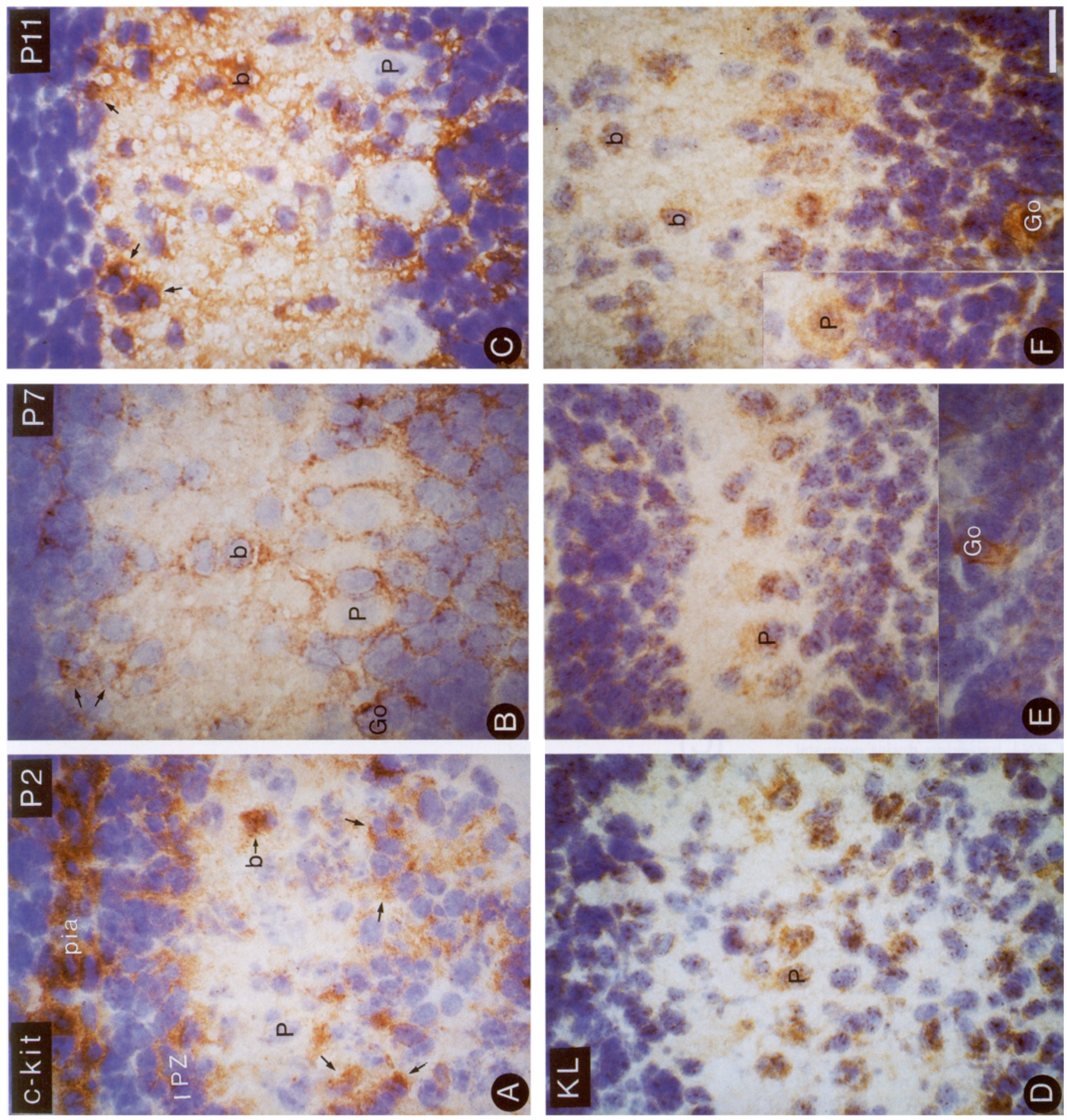
(A)

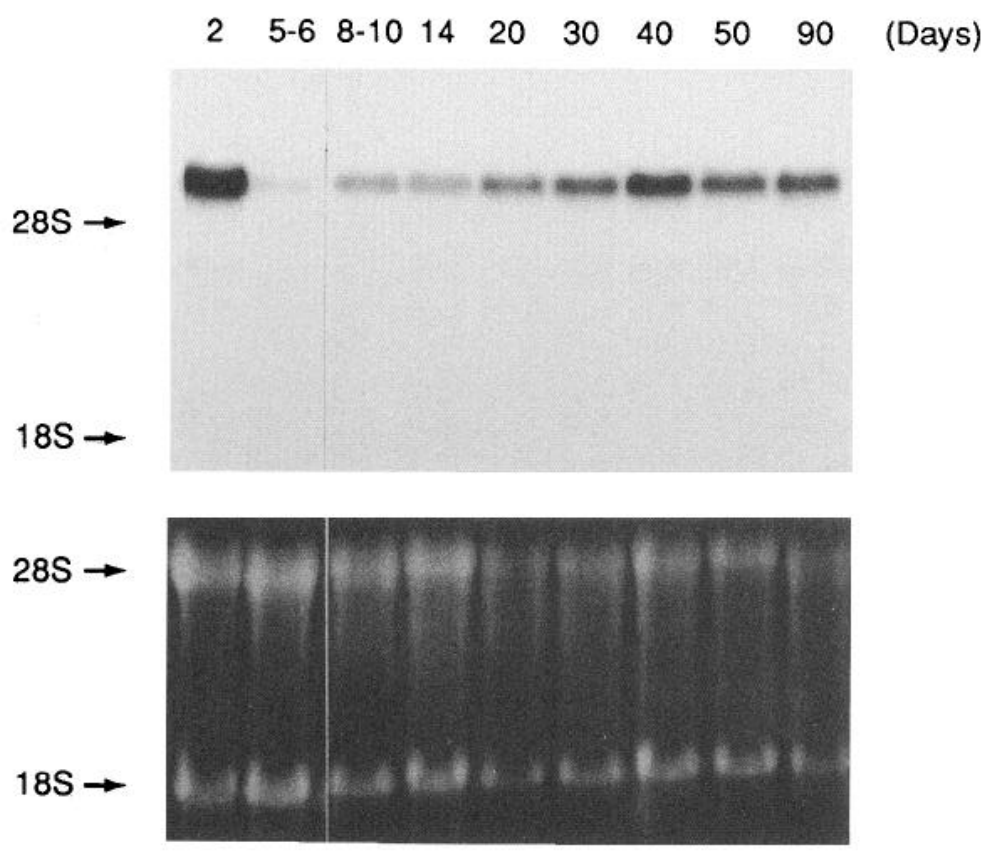

(B)

Figure 8. Expression of KL-1 and KL-2 RNA transcripts during postnatal development of the cerebellum. Total RNA from P2, P5-P6, P8-P10, P14, P20, P30, P40, P50, and P90 cerebellum was prepared in order to analyze KL RNA transcripts during postnatal development. $A$, Total RNA was fractionated by electrophoresis in an agarose gel, transferred to a nylon membrane, and hybridized with a ${ }^{32} \mathrm{P}$-labeled KL-specific RNA probe. The migration of $28 \mathrm{~S}$ and $18 \mathrm{~S}$ RNA is shown below. $B$, RNase mapping. Total RNA was processed for RNase protection assays as described in Materials and Methods, and the reaction products were analyzed by PAGE. The respective digestion products for KL-1 and KL-2 of 575 and 449 nucleotides are indicated. $C$, Determination of the relative ratio of KL-1 and KL-2 RNA transcripts. The relative intensities of the KL-1 and KL-2 signals were determined by a PhosphoImage analyzer (Molecular Dynamics) and the ratios determined accordingly.

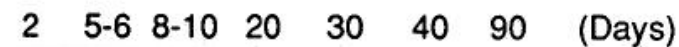

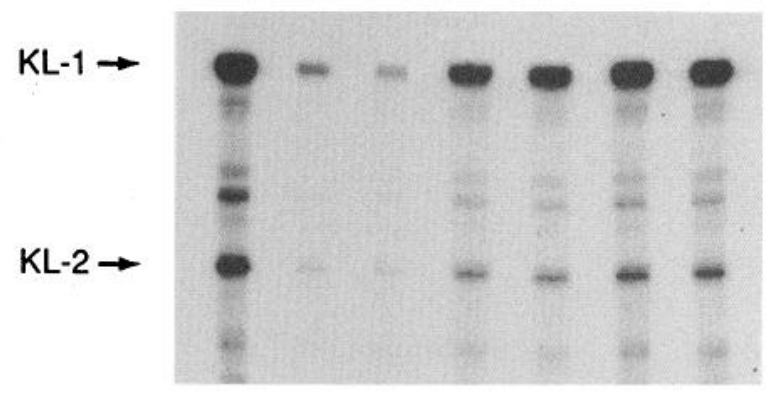

(C)

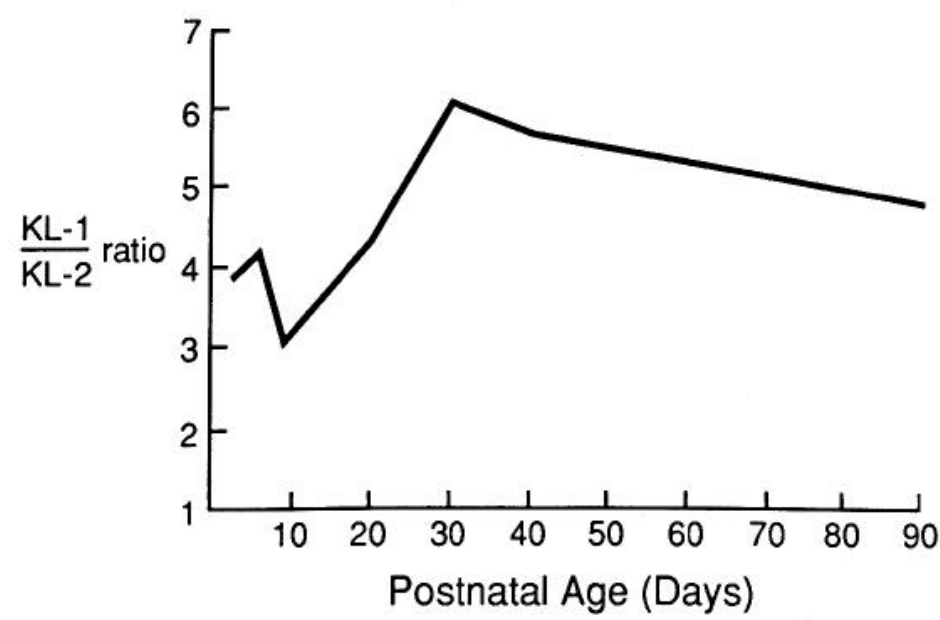

and granule cells, the in situ hybridization pattern of c-kit showed abundant scattered labeled cells in the broadening molecular layer, as well as progressively sparser labeled cells in the developing granular layer (Fig. $4 B, C$ ). No label was detected in the external germinal layer. At high magnification, it was apparent that newly formed basket and stellate cells were labeled, while descending granule cells and other small cells were not (Fig. 5B,C). Golgi cells were labeled throughout this time period 
as they became progressively dispersed by the arriving granule cells (Fig. $4 B, C$ ). Small cells in the future white matter also continued to express c-kit RNA.

Using immunohistochemical analysis to determine c-kit protein expression, at $\mathbf{P} 2$ staining was detected in the inner premigratory zone of the external germinal layer (Figs. $6 A, D ; 7 A$ ); postmitotic premigratory cells are concentrated in this region (Altman, 1976). A slight scattered accumulation of c-kit protein was detected in the Golgi cell layer. At P7, a light network of stained structures became apparent in the molecular layer (Figs. $6 E, 7 B)$. At higher magnification, the staining appeared to consist of the thin cytoplasmic rim of basket and stellate cells and their processes, and Golgi cell processes may contribute as well (Fig. 7B). Basket cell axons were beginning to form the "basket" around the Purkinje cell body. In the external germinal layer, c-kit staining was now present in scattered cells in the inner premigratory zone. We interpret the c-kit-expressing cells in this zone, at both P2 and P7, to be premigratory basket and stellate cells. Small individual cells scattered in the granular layer, presumably Golgi cells, were c-kit positive (Figs. 6E, 7B).

By P11, the molecular layer has thickened considerably, and a dense network of c-kit protein-containing structures was seen in this layer, including basket and stellate cell perikarya and their processes (Figs. $6 F, 7 C$ ). The formation of the "baskets" around the Purkinje cells continued and some cells in the premigratory zone of the external germinal layer remained c-kit positive (Fig. $7 \mathrm{C}$ ). In the granular layer, a coarse network of clumped stain appeared, similar to that of glomeruli, and small c-kit-positive cells were probably Golgi cells, (Altman 1976b). By P14, c-kit antibody revealed the beginning of sub-Purkinje accumulations of stain (developing pinceau structures), as well as stained Golgi and basket cell bodies (not shown).

$K L R N A$ and protein expression. Expression of KL RNA at 0 and $3 \mathrm{~d}$, determined by in situ hybridization, appeared as a thick band of highly labeled cells interdigitated with and just overlying the c-kit-expressing cells (Fig. $4 G$ ). The KL-labeled cells were identified cytologically as Purkinje cells by thcir size, packing density, and laminar position (Fig. $5 D$ ). Small neurons of the deep nuclei were also labeled. At P7 and P10, KL RNA was abundant in Purkinje cells (Fig. $4 H, I$ ).

At $\mathrm{P} 2, \mathrm{KL}$ protein, determined by immunohistochemistry, was expressed in Purkinje cells (Figs. 6G, 7D). At P7, Purkinje cells remained $\mathrm{KL}$ positive and presumed Golgi cells contained KL-specific cytoplasmic stain (Figs. $6 B, H ; 7 E$ ). At P11, in addition to continued $\mathrm{KL}$ protein expression as at $\mathrm{P} 7$, a low level of $\mathrm{KL}$ protein was discernible in the thin cytoplasm of some basket cells (Figs. 6I, 7F).

\section{Expression of $K L-1$ and $K L-2 R N A$ transcripts in postnatal cerebellum}

Two alternatively spliced KL RNA transcripts are known to encode different cell-associated KL protein products, KL-1 and $\mathrm{KL}-2$, which differ in their sequences $\mathrm{N}$-terminal of the transmembrane segment and are expressed in a tissue-specific manner (Flanagan et al., 1991; Huang et al., 1992). In the KL-2 protein product, sequences are missing, which include the major proteolytic cleavage site for the generation of the soluble $\mathrm{KL}$ protein product. While $\mathrm{KL}-1$ is processed very effectively to produce the soluble KL protein product, KL-2 represents a differentially more stable cell-associated form of KL. Therefore, $\mathrm{KL}-1$ is thought to promote processes that require the soluble and diffusible form of $\mathrm{KL}$, whereas $\mathrm{KL}-2$ may facilitate pro- cesses involving cellular interactions. In order to gain insight about the respective roles of KL-1 and KL-2 in postnatal cerebellar development, we determined the relative ratios of $\mathrm{KL}-1$ and KL-2 RNA transcripts in the cerebellum at different ages using RNA blot and RNase protection assays. The RNA blot analysis shown in Figure $8 A$ indicates a high level of expression of KI transcripts shortly after birth (P2), a sharp drop thereafter (P5-P6), and a subsequent gradual increase until a maximum level is reached in the mature cerebellum. These results suggest that Purkinje cell differentiation is accompanied by a major increase of $\mathrm{KL}$ transcripts on a per cell basis. RNase protection analysis of cerebellar RNA at maturity revealed a five- to sixfold excess of KL-1 over KL-2, while during the time of basket and stellate cell differentiation this excess was lower, that is, threeto fourfold (Fig. 8B,C). These results may suggest that the soluble form of $\mathrm{KL}$ plays a more prominent role in the mature cerebellum, while during the differentiation stage of the cerebellar interneurons, the cell-associated form KL-2 may play a role as well.

\section{Discussion}

The discovery that the c-kit receptor and its ligand $\mathrm{KL}$ are allelic with the murine $W$ and $S l$ loci, respectively, brought to light the function of the c-kit receptor system in melanogenesis, gametogenesis, and hematopoiesis, and accordingly, c-kit expression has been described in melanoblasts, germ cells, hematopoietic precursors, and mast cells. However, c-kit expression is also evident in cells and tissues other than those affected by the mutations, raising the issue of the function of the c-kit receptor in these cell systems. The experiments reported here, summarized in Table 1, examined the expression of $\mathrm{c}-k i t$ and its ligand in postnatal cerebellar development, to determine whether it is consistent with a functional role for c-kit during postnatal development and/or in the adult. Our findings are that c-kit receptor RNA and protein are expressed in basket, stellate, and Golgi neurons, while the Purkinje cells are the site of $\mathrm{KL}$ synthesis. Furthermorc, throughout postnatal development, c-kit is expressed in Golgi cells and KL in Purkinje cells, while in basket and stellate cells c-kit is expressed from their time of birth. In addition, KL protein was detected in Golgi cells from P7 and in basket and stellate cells from P11 onward, suggesting functional interactions of $\mathrm{KL}$ with the c-kit receptor in these cells.

The simultaneous expression of c-kit in inhibitory interneurons and $\mathrm{KL}$ in Purkinje neurons is striking and suggestive of a role for c-kit in the cerebellum. By analogy with neurotrophic. growth factors for which a similar cellular relationship exists between receptor- and ligand-expressing cells, KL in Purkinje cells may facilitate in vivo survival of the cerebellar basket and stellate neurons, the innervation of their target cells and synaptic organization, as well as later intracellular events involved in the control of neurotransmitter release and neurotransmitter receptor function (Hopfield et al., 1988; Pang et al., 1988; Barde, 1989; Qu et al., 1990). Although many mutations are known at the $W$ and $S l$ loci, no neurologic phenotypes have been noted in these mice. It may be that, as a result of redundancies, other signaling mechanisms compensate for the lack of c-kit function in neuronal cells. Loss-of-function mutations in the Drosophila $a b l$ and fasciclin I genes by themselves do not display a phenotype, but in double-homozygous mutant flies profound deficiencies in axon outgrowth and guidance are observed (Elkins et al., 1990). Therefore, genetic evidence for c-kit function in 
Table 1. Summary of expression of c-kit and KL proteins in the developing cerebellum

\begin{tabular}{|c|c|c|c|c|c|c|c|c|}
\hline \multirow[b]{2}{*}{ Age } & \multirow[b]{2}{*}{ Cellular events } & \multicolumn{4}{|c|}{ Expression of c-kit } & \multicolumn{3}{|c|}{$\underline{\text { Expression of } K \mathbf{K}^{a}}$} \\
\hline & & $\begin{array}{l}\text { Pur- } \\
\text { kinje }\end{array}$ & Golgi & Basket/stellate & IPZ & Purkinje & Golgi & $\begin{array}{l}\text { Basket } \\
\text { stellate }\end{array}$ \\
\hline $\mathrm{P} 2$ & Proliferation of EGL & & + & & + & + & & \\
\hline P7 & $\begin{array}{l}\text { Birth of basket, stellate, and } \\
\text { granule cells; initial growth of } \\
\text { processes }\end{array}$ & & + & + & $+1-$ & + & $(+)$ & \\
\hline P11 & $\begin{array}{l}\text { Birth of stellate and granule cells; } \\
\text { growth of neuronal processes } \\
\text { and synaptogenesis }\end{array}$ & & + & + & & $\begin{array}{l}+ \text { and } \\
\text { dendrites }\end{array}$ & $(+)$ & $(+)$ \\
\hline $\mathrm{P} 14$ & Same as P11 & & + & $\begin{array}{l}+ \text { processes } \\
\text { and pinceaux }\end{array}$ & & $\begin{array}{l}++ \text { and } \\
\text { dendrites }\end{array}$ & $(+)$ & $(+)$ \\
\hline
\end{tabular}

${ }^{a} \mathrm{KL}$ protein staining in the absence of KL RNA expression is indicated by (+).

the CNS may have to await analysis of mice carrying double mutations. It is known that the genetic removal of mature Purkinje cells in mice homozygous for the Purkinje cell degeneration mutation (pcd) does not affect the survival or integrity of mature basket and stellate cells (Landis and Mullen, 1978), and this is in agreement with the lack of a neurological phenotype and lack of morphological abnormalities in mice with severe $W$ mutations. On the other hand, radioablation of basket or stellate cells in early postnatal development has been shown to result in the formation of multipolar dendritic trees or defective branching of dendritic shafts of Purkinje cells, respectively (Altman, 1976ac), and this may suggest that basket and stellate cells are essential for the formation of the dendritic structures of Purkinje cells possibly by way of production of soluble or cell-bound neurotrophic factors. The formation of the dendritic trees of Purkinjc cells and of the axon structures of basket and stellate cells then appears to be intimately related.

The soluble and the cell surface-associated forms of $\mathrm{KL}$ provide means to generate diverse responses. During development, $\mathrm{KL}$ may be involved in several functions, including regulation of basket and stellate cell innervation by Purkinje cells. Ramon y Cajal (1911) proposed chemotropism as a mechanism for axon outgrowth and guidance, and recent evidence suggests that factors produced by target cells facilitate these processes (TessierLavigne and Placzek, 1991). The soluble form of KL has been shown to promote chemotaxis of mast cells and of c-kit-expressing endothelial cells (Blume-Jensen et al., 1991; Meininger et al., 1992). Based on this property, a gradient of soluble KL produced by the Purkinje cells could contribute to the guidance of basket and stellate axons. Alternatively, the cell membrane form of $\mathrm{KL}$ may facilitate cell-cell-mediated signals and may function during synapse formation. In agreement with this notion, the relative amount of KL-2 transcripts encoding the predominant cell-associated KL protein product is higher in younger animals at the time of synaptogenesis.

Basket, stellate, and Golgi cell bodies displayed perinuclear reactivity with the KL antibody. Ligand-receptor complexes are known to be internalized and then processed for degradation or for recycling of the receptor to the cell surface. In the case of NGF, NGF-receptor complexes formed at the axon terminals are carried by retrograde transport to the cell body for degradation or further as yet unknown events of signal transduction (Korsching and Thoenen, 1983; Palmetier et al., 1984; Raivich et al., 1991). Thus, accumulation of KL-reactive material in the basket and stellate cell bodies, in the absence of detectable $\mathrm{KL}$ RNA, may represent KL-receptor complexes formed at axon terminals or at any point on the cell surface, accumulated by retrograde transport. Supporting the view that $\mathrm{KL}$ seen in basket, stellate, and Golgi cells represents internalized factor, experiments with KL antibody specific for cyloplasmic determinants of KL showed staining of Purkinje cells and their processes but not of basket, stellate, and Golgi cells. The presence of KLreactive material in these cells then should be interpreted as indicating c-kit receptor function. Therefore, our results may suggest onset of functional activity by at least $\mathrm{P} 7$ for Golgi cells and by at least P11 for basket and stellate cells.

Our developmental analysis demonstrates that $\mathrm{KL}$ is produced by Purkinje cells and c-kit by Golgi cells during the entire time period studied, that is, from P0 onward, indicating the possibility of functional interactions from this early time. Low levels of expression of $\mathrm{c}-k i t$ and $\mathrm{KL}$ have been detected in fetal cerebellum by in situ hybridization (K. Manova, R. F. Bachvarova, E. J. Huang, S. Sanchez, S. M. Pronovost, E. Velazquez, B. McGuire, and P. Besmer, unpublished observations), but it is not clear yet whether significant amounts of protein are made at this time. Basket and stellate cells express c-kit from a time soon after their birth in the generative zone of the external germinal layer, since we could detect c-kit-expressing cells in the inner premigratory zone of the external germinal layer. This timing of the onset of expression of c-kit is common to many other neurons, including those of the spinal cord and hindbrain, where they are first labeled as postmitotic neurons leaving the generative ventricular layer (Keshet et al., 1991; Manova, Bachvarova, Huang, Sanchez, Pronovost, Velazquez, McGuire, and Besmer, unpublished observations).

Classically, basket and stellate cells were thought to be derived from the external germinal layer. Recently, evidence suggesting that basket and stellate cells do not originate from the external germinal layer has been presented. Using chicken/quail chimeras, Hallonet et al. (1990) found that a medial portion of the rostral cerebellum consisted of granule cells derived from the metencephalon, while basket, stellate, Purkinje, and Golgi cclls were of mesencephalic origin. However, in similar experiments, Martinez and Alvarado-Mallart (1989) found that all neurons in this region were of mesencephalic origin. The simplest interpretation of our data is that the c-kit-expressing cells in the inner zone of the external germinal layer at P2 and P7 are progenitors of basket and stellate cells. Whether these cells arise 
from a precursor common to basket, stellate, and granule cells remains to be determined.

$\begin{array}{ll}\text { Appendix } \\ \text { Abbreviations for figures } \\ \text { b } & \text { Basket cell } \\ \text { dcn } & \text { Deep cerebellar nucleus } \\ \text { dgr } & \text { Presumed descending granule cell } \\ \text { EGL } & \text { External germinal layer } \\ \text { gl } & \text { Presumed glial cell } \\ \text { GL } & \text { Granular layer } \\ \text { Go } & \text { Golgi cell } \\ \text { gr } & \text { Granule cell } \\ \text { IPZ } & \text { Inner premigratory zone } \\ \text { ML } & \text { Molecular layer } \\ \text { P } & \text { Purkinje cell } \\ \text { pia } & \text { Pia mater } \\ \text { PL } & \text { Purkinje layer } \\ \text { s } & \text { Stellate cell } \\ \text { WM } & \text { White matter }\end{array}$

\section{References}

Altman J (1969) Autoradiographic and histological studies of postnatal neurogenesis. III. Dating the time of production and onset of differentiation of cerebellar microneurons in rats. J Comp Neurol 136:269294.

Altman J (1972) Postnatal development of the cerebellar cortex in the rat. J Comp Neurol 145:353-514.

Altman J (1976a) Experimental reorganization of the cerebellar cortex. $\mathrm{V}$. Effects of early $\mathrm{x}$-irradiation schedules that allow or prevent the acquisition of basket cells. J Comp Neurol 165:31-48.

Altman I (1976b) Experimental reorganization of the cerebellar cortex. VI. Effects of x-irradiation schedules that allow or prevent the acquisition after basket cells are formed. J Comp Neurol 165:49-64.

Altman J (1976c) Experimental reorganization of the cerebellar cortex. VII. Effects of late $\mathrm{x}$-irradiation schedules that interfere with cell acquisition after stellate cells are formed. J Comp Neurol 165:65-76.

Altman J (1982) Morphological development in the rat cerebcllum and some of its mechanisms. Exp Brain Res [Suppl] 6:8-49.

Altman J, Bayer SA (1985) Embryonic development of the rat cerebellum. J Comp Neurol 231:1-64.

Anderson DM, Lyman SD, Baird A, Wignall JM, Eisenman J, Rauch C, March CJ, Boswell HS, Gimpel SD, Cosman D, Williams DE (1990) Molecular cloning of mast cell growth factor, a hematopoietin that is active in both membrane bound and soluble forms. Cell 63: 235-243.

Angevine JB, Sidman RL (1961) Autoradiographic study of cell migration during histogenesis of cerebral cortex in the mouse. Nature 192:766-768.

Barde YA (1989) Trophic factors and neuronal survival. Neuron 2: $1525-1534$.

Basler K, Hafen E (1988) Control of photoreceptor cell fatc by the sevenless protein requires a functional tyrosine kinase domain. Cell 54:299-311.

Besmer P, Murphy PC, George PC, Qiu F, Bergold PJ, Lederman L, Snyder HW, Brodeur D, Zuckerman EE, Hardy WD (1986) A new acute transforming feline retrovirus and relation of its oncogene $v$ kit with the protein kinase gene family. Nature 320:415-421.

Blume-Jensen P, Claesson-Welsh L, Siegbahn A, Zsebo KM, Westermark B, Heldin C-H (1991) Activation of the human c-kit product by ligand-induced dimerization mediates circular actin reorganization and chemotaxis. EMBO J 10:4121-4128.

Chabot B, Stephenson DA, Chapman VM, Besmer P, Bernstein A (1988) The proto-oncogene c-kit encoding a transmembrane tyrosine kinase receptor maps to the mouse $W$ locus. Nature 335:88-89.

Copeland NG, Gilbert DJ, Cho BC, Donovan PJ, Jenkins NA, Cosman D, Anderson D, Lyman SD, Williams DE (1990) Mast cell growth factor maps near the Steel locus on mouse chromosome 10 and is deleted in a number of Steel alleles. Cell 63:175-183.

Elkins T, Zinn K, McAllister L, Hoffmann FM, Goodman CS (1990) Genetic analysis of a Drosophila neural cell adhesion molecule: interaction of fasciclin I and Abelson tyrosine kinase mutations. Cell $60: 565-575$.
Flanagan JG, Leder P (1990) The kit ligand: a cell surface molecule altered in steel mutant fibroblasts. Cell 63:185-194.

Flanagan JG, Chan D, Leder P (1991) Transmembrane form of the c-kit ligand growth factor is determined by alternative splicing and is missing in the $S l^{\mathrm{d}}$ mutation. Cell 64:1025-1035.

Fujita S (1967) Quantitative analysis of cell proliferation and differentiation of the postnatal mouse cerebellum. J Cell Biol 32:277-287.

Fujita S, Shimida M, Nakamura T (1966) ${ }^{3} \mathrm{H}$-thymidine autoradiographic studies on the cell proliferation and differentiation in the external granular layers of the mouse cerebellum. J Comp Neurol 128: 191-208.

Geissler EN, Ryan MA, Housman DE (1988) The dominant whitespotting $(W)$ locus of the mouse encodes the c-kit proto-oncogene. Cell 55:185-192.

Gluzman Y (1981) SV40-transformed simian cells support the replication of early SV40 mutants. Cell 23:175-182.

Gordon MY (1991) Hematopoietic growth factors: bound and free. Cancer Cells (Cold Spring Harbor) 3:127-133.

Hafen E, Basler K, Edstroem JE, Rubin GM (1987) Sevenless, a cellspecific homeotic gene of Drosophila, encodes a putative transmembrane receptor with a tyrosine kinase domain. Science 236:55-63.

Hallonet MER, Teillet MA, LeDouarin NM (1990) A new approach to the development of the cerebellum provided by the quail-chick marker system. Development 108:19-31.

Hatten ME, Lynch M, Rydel RE, Sanchez J, Joseph-Silverstein J, Moscatelli D, Rifkin DB (1988) In vitro neurite extension by granule neurons is dependent upon astroglial-derived fibroblast growth factor. Dev Biol 125:280-289.

Hopfield JF, Tank DW, Greengard P, Huganir RL (1988) Functional modulation of the nicotinic acetylcholine receptor by tyrosine phosphorylation. Nature 336:677-680.

Ito $M$ (1984) The cerebellum and neural control. New York: Raven.

Jacobson M (1978) Developmental neurobiology. London: Plenum.

Kaplan DR, Hempstead BL, Martin-Zanca D, Chao MV, Parada LF (1991) The $t r k$ proto-oncogene product: a signal transducing receptor for nerve growth factor. Science 252:554-557.

Klein R, Martin-Zanca D, Barbacid M, Parada LF (1990) Expression of the tyrosine kinase receptor gene $\operatorname{trk} \mathrm{B}$ is confined to the murine embryonic and adult nervous system. Development 109:845-850.

Korsching S, Thoenen H (1983) Quantitative demonstration of retrograde transport of endogenous nerve growth factor. Neurosci Lett $39: 1-4$.

Lai C, Lemke G (1991) An extended family of protein tyrosine kinase genes differentially expressed in the vertebrate nervous system. Neuron 6:691-704.

Lamballe F, Klein R, Barbacid M (1991) trkC, a new member of the trk family of tyrosine protein kinases, is a receptor for neurotrophin3. Cell 66:967-979.

Landis SC, Mullen RJ (1978) The development and degeneration of Purkinje cells in $p c d$ mutant mice. J Comp Neurol 177:125-143.

Lee DC, Rose TM, Webb NR, Todaro GJ (1985) Cloning and sequence analysis of a cDNA for rat transforming growth factor- $\alpha$. Nature 313: 489-491.

Majumder S, Brown K, Qiu F-H, Bcsmer P (1988) c-kit protein, a transmembrane kinase: identification in tissues and characterization. Mol Cell Biol 8:4896-4903.

Manova K, Bachvarova RF (1991) Expression of c-kit encoded at the $W$ locus of mice in developing embryonic germ cells and presumptive melanoblasts. Dev Biol 146:312-324.

Manova K, Nocka K, Besmer P, Bachvarova RF (1990) Gonadal expression of c-kit encoded at the $W$ locus of the mouse. Development 110:1057-1069.

Martinez S, Alvarado-Mallart R-M (1989) Rostral cerebellum originates from the caudal portion of the so-called 'mesencephalic' vesicle: a study using the chick/quail chimeras. Eur J Neurosci 1:549-560.

Matsui Y, Zsebo KM, Hogan BLM (1990) Embryonic expression of a haematopoietic growth factor encoded by the $S /$ locus and the ligand for c-kit. Nature 347:667-669.

Meininger CJ, Yano H, Rottapel R, Bernstein A, Zsebo KM, Zetter BR (1992) The c-kit receptor ligand functions as a mast cell chemotractant. Blood 79:958-963.

Miale IL, Sidman RL (1961) An autoradiographic analysis of histogenesis in the mouse cerebellum. Exp Neurol 4:277-296.

Noble M, Murray K, Stroobant P, Waterfield MD, Riddle P (1988) Platelet derived growth factor promotes division and motility and 
inhibits premature differentiation of the oligodendrocyte/type 2 astrocyte progenitor cell. Nature 333:560-562.

Nocka K, Majumder S, Chabot B, Ray P, Cervone M, Bernstein A, Besmer P (1989) Expression of c-kit gene products in cellular targets of $W$ mutations in normal and $W$ mutant mice-evidence for an impaired c-kit kinase in mutant mice. Genes Dev 3:816-826.

Nocka K, Tan J, Chiu E, Chu TY, Ray P, Traktman P, Besmer P (1990a) Molecular basis of dominant negative and loss of function mutations at the murine c-kit/white spotting locus: $W^{37}, W^{\mathrm{v}}, W^{4 !}, W$. EMBO J 9:1805-1813.

Nocka K, Buck J, Levi E, Besmer P (1990b) Candidate ligand for the c-kit transmembrane kinase receptor: $\mathrm{KL}$, a fibroblast-derived growth factor stimulates mast cells and erythroid progenitors. EMBO J 9: 3287-3294.

Nocka K, Huang E, Beier DR, Chu TY, Buck J, Lahm HW, Wellner $D$, Leder P, Besmer P (1990c) The hematopoietic growth factor KL is encoded by the $S l$ locus and is the ligand of the c-kit receptor, the gene product of the $W$ locus. Cell 63:225-233.

Orr-Urtreger A, Avivi A, Zimmer Y, Givol D, Yarden Y, Lonai P (1990) Developmental expression of $c$-kit, a proto-oncogene encoded by the $W$ locus. Development 109:911-923.

Palay SL, Chan-Palay V (1974) Cerebellar cortex: cytology and organization. New York: Springer.

Palmetier MA, Hartman BK, Johnson EM (1984) Demonstration of retrogradely transported endogenous nerve growth factor in axons of sympathetic neurons. J Neurosci 4:751-756.

Pang DT, Wang JKR, Valtorta F, Benfenati F, Greengard P (1988) Protein tyrosine phosphorylation in synaptic vesicles. Proc Natl Acad Sci USA 85:762-766.

Qiu F, Ray P, Brown K, Barker PE, Jhanwar S, Ruddle RH, Besmer P (1988) Primary structure of c-kit: relationship with the CSF-1/PDGF receptor kinase family - oncogenic activation of $c-k i t$ involves deletion of extracellular domain and C-terminus. EMBO J 7:1003-1011.

Qu Z, Moritz E, Huganir RL (1990) Regulation of tyrosine phosphorylation of the nicotinic acetylcholine receptor at the rat neuromuscular junction. Neuron 4:367-378.

Raff MC, Lillien LE, Richardson WD, Burne JF, Noble MD (1988) Platelet-derived growth factor from astrocytes drives the clock that times oligodendrocyte development in culture. Nature 333:562-565.

Raivich G, IIellweg R, Kreutzberg GW (1991) NGF receptor mediated reduction in axonal NGF uptake and retrograde transport following sciatic nerve injury and during regeneration. Neuron 7:151-164.

Rakic P (1971) Neuro-glia relationship during granule cell migration in developing cerebellar cortex. A Golgi and electron microscopic study in Macacus rhesus. J Comp Neurol 141:283-312.

Rakic P (1985) Mechanisms of cell migration in the developing cerebellar cortex. In: Molecular bases of neuronal development (Edelman G, Gall WE, Cowan WM, eds), pp 139-160. New York: Wiley.

Ramon y Cajal S (1911) Histologie du systeme nerveux de l'homme et des vertebres. Paris: Maloine.

Rettenmier CW (1989) Biosynthesis of macrophage colony-stimulating factor (CSF-1): differential processing of CSF-1 precursors suggests alternative mechanisms for stimulating CSF-1 receptors. Curr Top Microbiol Immunol 149:129-141.
Rettenmier CW, Roussel MF (1988) Differential processing of colonystimulating factor 1 precursors encoded by two human cDNAs. Mol Cell Biol 8:5026-5034.

Russell ES (1979) Hereditary anemias of the mouse: a review for geneticists. Adv Genet 20:357-459.

Rydel RE, Green LA (1987) Acidic and basic fibroblast growth factors promote stable neurite outgrowth and neuronal differentiation in cultures of PC12 cells. J Neurosci 7:3639-3653.

Silvers WK (1979) White-spotting, patch and rump-whitc. In: The coat colors of mice: a model for gene action and interaction, pp 206241. New York: Springer.

Squinto SP, Stitt TN, Aldrich TH, Davis S, Bianco SM, Radziejewski C, Glass DJ, Masiakowski P, Furth ME, Valenzuela DM, DiStefano PS, Yancopoulos GD (1991) trkB encodes a functional receptor for brain-derived neurotropic factor and neurotropin-3 but not nerve growth factor. Cell 65:885-893.

Tan JC, Nocka K, Ray P, Traktman P, Bèsmer P (1990) The dominant $W^{42}$ spotting phenotype results from a missense mutation in the ckit receptor kinase. Science 247:209-212.

Tessier-Lavigne M, Placzek M (1991) Target attraction: are developing axons guided by chemotropism? Trends Neurosci 14:303-310.

Trenckner E, Smith D, Segil N (1984) Is cerebellar granule cell migration regulated by an intcrnal clock? J Neurosci 4:2850-2855.

Tushinski RJ, Oliver IT, Guilbert LJ, Tynan PW, Warner JR, Stanley ER (1982) Survival of mononuclear phagocytes depends on a lineage-specific growth factor that the differentiated cells selectively destroy. Cell 28:71-81.

Walicke PA, Cowan WM, Ueno N, Baird A, Guillemin R (1986) Fibroblast growth factor promotes survival of dissociated hippocampal neurons and enhances neurite extension. Proc Natl Acad Sci USA 83:3012-3016.

Williams DE, Eisenman J, Baird A, Rauch C, Ness KV, March CJ, Park LS, Martin U, Mochizuki DY, Boswell HS, Burgess GS, Cosman D, Lyman SD (1990) Identification of a ligand for the c-kit protooncogene. Cell 63:167-174.

Yarden Y, Kuang WJ, Yang-Feng T, Coussens L, Munemitsu S, Dull TJ, Chen E, Schlessinger J, Francke U, Ullrich A (1987) Iluman proto-oncogene c-kit: a new cell surface receptor tyrosine kinase for and unidentified ligand. EMBO J 6:3341-3351.

Yeh HJ, Ruit KG, Wang YX, Parks WC, Snider WD, Deuel TF (1991) PDGF-A chain gene is expressed by mammalian neurons during development and in maturity. Cell 64:209-216.

Zsebo KM, Wypych J, McNiece IK, Lu HS, Smith KA, Karkare SB, Sachdev RK, Yuschenkoff VN, Birkett NC, Williams LR, Satyagal VN, Tung W, Bosselman RA, Mendiaz EA, Langley KE (1990a) Identification, purification, and biological characterization of hematopoietic stem cell factor from Buffalo rat liver conditioned medium. Cell 63:195-201.

Zsebo KM, Williams DA, Geissler EN, Broudy VC, Martin FH, Atkins HL, Hsu RY, Birkett NC, Okino KH, Murdock DC, Jacobsen FW, Langley KE, Smith KA, Takeishi T, Cattanach BM, Galli SJ, Suggs SV (1990b) Stem cell factor is encoded at the $S /$ locus of the mouse and is the ligand for the c-kit tyrosine kinase receptor. Cell 63:213224. 